\title{
What Unites India?: On the Role of Translation and Culture in Producing the Nation ${ }^{1}$
}

\section{Sushumna Kannan}

\begin{abstract}
:
The Two-Worlds theory is a specific result of postcolonial grids of thought that provoke us to rethink the role of English as opposed to that of the vernacular languages of India. All too often, arguments take the form of defending the vernacular and questioning the role of English. Significantly enough, a connection is drawn between the role of English and its function as a proxy for nationalism. This paper examines the theoretical frameworks that articulate such connections and raises some questions with regard to the Two-Worlds theory in Literary and Translation Studies, while charting the current intellectual milieu. Methodologically, the paper discusses underlying assumptions about concepts of culture, nationalism, colonialism and Orientalism.
\end{abstract}

Keywords: Nation, Postcolonialism, Two-Worlds Theory, IWE, Indian Literature.

\section{Introduction:}

The Two-Worlds theory in Translation Studies is made up of various anxieties about the increasingly strong position of English in changing times and the status of the 'endangered' native, regional, vernacular language and Bhasha literatures. The theory concerns itself with far deeper historical questions of how and why English came to pervade in India and other postcolonial contexts and what we should do with it. The inequality that persists between English and the vernacular languages of India is increasingly a marker of class, gendered ways of being as well as modernity. ${ }^{2}$ It is as a result of English, so to speak, that many 
Indians have emerged; its acknowledgement entering popular parlance. Consequently, scholars in the area have attempted to solve the puzzle of why English is the language into which translations from vernaculars take place when indeed other vernaculars have a better translatability. Although postcolonial Translation Studies begins with a dyad of recognition-English is both colonizer and native, desirable and yet dominatingequalizing the disparity between English and world of vernaculars has remained a challenge.

Indian writing in English as well as translations from vernaculars to English, it could be argued, increases the expressive possibilities of the language as well as its conceptual possibilities that could be for the better. That is, expanding English to suit the realities of India will, so to speak, push against the limits of thought as well. In the final run, it could lead to a deeper understanding of India both within and without, in India and the west, thus somewhat reversing colonialism or speaking back. Yet, it could be argued that we are growing English at the cost of our vernaculars. This latter argument could hold some truth despite the fact that there is great respect for Indian writing in English and its translations today, across the global literary scape. ${ }^{3}$ Again, it could be argued that while English continues to be the dominating language and this has given rise to protests and demands for the preservation and nurturing of vernacular languages and literatures, English itself has also been domesticated and internalized. 'Indian English' is thus seen today as legitimate in its own right.

Perhaps the only consensual starting point to address the realities of the Two Worlds is to acknowledge that a generation of people are comfortable with English more than any other vernacular. That said, it is a fact that more and more Indians are bilingual today (Devy, 1995:13) with one language being the regional language or mother-tongue and the other being English. Often, due to migration as well as urbanization, the mother tongue is a language that one does not know how to read and write in, but can speak, leaving English as a language for written communication. ${ }^{4}$ 
The Two Worlds theory invokes a discussion of nationhood in at least two ways, within the area of Translation and Literary Studies, both sufficiently interesting for the questions we will raise in the forthcoming sections. One has to do with the nomenclature Indian Literature, its content, reference and relevance. The second has to do with the role of translation in unifying India. With reference to the first nomenclature of Indian Literature, scholars have borrowed from critiques of nationalism, viewed the nation as an imagined community, related it to the division of states in India on linguistic basis and pointed to the violence of homogenizing disparate linguistic cultures into one. As for the second issue of unifying India through translation, scholars have pointed out that the very idea of one nation, India, became possible with English and translations into it.

In both the historical account of how English came to dominate in India and in contemporary discussions on the issue, several scholars point to how nationalism invokes the idea of a national language and trace how Hindi, although is the largest spoken language in India, came to be only ceremonial rather than communicative. We are told that urban centers with their upper class leanings ensured that English was seen as the language of sophistication as opposed to the vernacular ones. ${ }^{5}$ An important part of these discussions claim that nationhood is itself made possible by translation. We are told that

...translations into English from the regions have become a major means of representing, embodying and concretizing the abstract notion of one 'India' in a multilingual, multicultural and multiethnic society. The task of narrativizing the nation using 'homogenized' English translations seems to have become one of the primary agendas of translation in the country. A prioritizing of such translational processes poses a grave threat, the threat of eradicating multiplicities and destroying regional flavours and variety. Such translations would enable English to become an assimilating front for the regional languages 
and literatures of India. (Concept note of the seminar, Translating India into English, 2008).

In this paper, I will respond to ideas of nationhood and translation, and accompanying accounts of colonialism and Orientalism as articulated in the Two Worlds theory and Translation and Literary Studies in general. I will argue that some of the assumptions in the connections drawn between translation and nationhood are the results of weak accounts of Indian history. Then, by arguing for a deeper understanding of the culture concept, I aim to show that an alternative view of 'Indian Literature' 'Indian Writing in English' as well as 'Indian Writing in English Translation' is possible. This alternative view hopefully allows us to make different sense of our current anxieties about English 'taking over' and also helps us to reconstruct our own past better.

\section{Translation and the Nation:}

\section{a. The Indian in 'Indian Literature'}

A critique of the 'Indian' in Indian Literature is more often than otherwise borrowed from critiques of nationalism in theoretical disciplines such as History and Cultural Studies. This is most evident in Literary writing in Amitav Ghosh's novels. His subsequent essay in one of the Subaltern Studies volumes confirms the role of theory informing literary writing. As I discuss critiques of nationalism in the following sections, I use Ghosh, but praise for his Shadow Lines often misses an assessment of the theoretical influences that shape his literary writings and an analysis of the final result. In larger literary discussions, however, the role of ideology in literary writing is increasingly questioned and/or defended. Before I articulate what I see as the issue at stake in borrowing critiques of nationalism for critiquing the category of 'Indian Literature in the next section,'I will cull-out a few issues of importance here.

Firstly, critiques of nationalism or the Nation-State, 
associate it with constitutive issues while they are capable of acting as merely effective organizational entities. Attributing constitutive violence to the Nation-State can be problematic since some of our best pro-people movements, like The Narmada Bachao Andolan, by experience have acknowledged the possible usefulness of working with the Nation State. Consequently, anyone thinking about nationalism today needs to factor in the nature of technological advancements, capitalism, free market economies as well traditional thought that viewed the world as one or practiced filial piety. New political developments and citizen activism along with traditional NGO activism needs to be accounted today before we conclude on the ineffectiveness of the Nation-State per se. ${ }^{6}$ My contention with attributing homogenizing tendencies to the Nation-State as constitutive of it, is the same. With a continued practice of identity politics, while its limitations are taken into account, over time, it could be possible to fight the homogenizing and labeling tendencies Nation-States are known to practice. More importantly, it can be argued that nationalism has a relative value is not an absolute evil. As the rhetoric goes: Countries have the governments they deserve and in democracies, people get the leaders they deserve. We also have to remember that nationalism in India also coincides with postcolonialism and effective responses to colonization. It encompasses a genuine indigenous response to the event of colonialism although this urgency may have caused it to overlook a number of crucial issues. The question then is whether we can rectify these issues, perhaps not of attributing constitutive violence to it.

Secondly, in Europe, language played an important role in the creation of identities as well as nations. This phenomenon is somewhat different in India with multiple identities playing a role, language being just one among them. For India, nationhood along linguistic lines was impossible and was reworked. At best, an ill-fitting import, nationalism was once-removed from the true preoccupations of Indians. It would be a fallacy to assume that Benedict Anderson's theses on Europe can unproblematically hold true for India. Even where the nationalist discourse played itself 
out in India, a number of other values were emphasized upon, rather than the singular discourse of nationhood dominating. For example, even a writer such as Bankim Chandra wrote very few nationalistic works and more romances in the corpus of his entire literary output. Also, ecological concerns, Gandhian notions and other contending positions captured the imagination of the people, and nationhood was an aim to self-govern, a task understood to be too complex for mere patriotic sentiments.

Hence, as I see it, the important issue in debates about Indian Literature and the problematization of the contents of the 'Indian,' (who and what qualifies to be slotted under this category) is that our critical practice leaves the creative writer defensive. That is, determining the Indian-ness of a certain work becomes an issue because of the postcolonial theoretical project to figure out the power imbalances in writers of different languages and locations and their literary stances. Instead, what should be addressed is that we are yet to develop a mid-point or approach that does not devalue either the creative writer or the critic. In fact, the divide between these two is so magnified that some years ago, I experienced firsthand how students of two different departments Literature and Cultural Studies, within the school of Humanities, at CIEFL found it impossible to engage in meaningful dialogues. This experience though not fully unpacked reached a debating point when Vikram Chandra wrote "Cult of Authenticity" responding to Mukherjee's "The anxiety of Indianness." In this now well-known essay, Chandra critiques Mukherjee for excessive preoccupation with Indian-ness and the location of authors instead of assessing their work sans ad hominem references and for their worth as a work of art. He articulates his predicament by saying: "To delight in the mundane is what an artist does..." and asks: "How should a writer work, in these circumstances? What must an Indian artist do?" 7 Ghosh too addresses this issue, though he leans more towards a politically engaging model of creative writing:

We who write fiction, even when we deal with matters of public significance have no choice, no matter how lush and 
or extravagant our fictions, but to represent events as they are refracted through our characters. Our point of entry into even the largest of events is inevitably local, situated in and focussed on details and particulars. To write of any event in this way is necessarily to neglect its political contexts... what then are the contexts that we, as writers of fiction, can properly supply? It seems to me that they must lie in the event itself, the scene, if you like it must be in some part the reader's responsibility to situate the events within broader contexts to populate the scene with the products of his experience and learning. A reader who reads the scene literally or mean spiritedly must surely bear some part of the blame for that reading. (Ghosh, 2001: 282-3).

Again, issues herein appear to arise from an acceptance of specific critiques of nationalism and postcolonial theory. But we must note that both Chandra and Ghosh, by drawing our attention to the writing process seem to be questioning the longassumed validity of post-structuralism as applied to literary works. That is, the collusion of postcolonialism and post-structuralism create theoretical frameworks that cannot sit with the processes of creative writing practices. Post-structuralist understandings of language and meaning-making are used somewhat simplistically, deploying the work of scholars such as Derrida in strategic ways that do not correspond to the original contextual intentions and arguments. So we are faced with a situation where, universalism remains to be a virtue, worthy of aim and achievement in art and literature, post colonialism questions it in a manner that cripples it. The validity of even a Pollock's definition of the classic as "what gives access to radically different forms of human consciousness for any given generation of readers, and thereby expands for them the range of possibilities of what it means to be a human being." (2011: 36) remain somewhat irrelevant in our current critical practices. This is indeed the sad state of affairs that Pollock formulates as "Crisis in the Classics" as well. Dharwadker addresses the predicament of the creative writer, writing about $A$ $\mathrm{K}$ Ramanujan that clarifies my point with regard to anxieties about 
the Indian in both Indian Literature as well as Indian writing in English:

In contrast to Ramanujan's way of thinking, post-structuralist thought is so context-centred ... that it divorces theory from practice, makes practice on the basis of such theorizing impossible (or, for Ramanujan at least, inconceivable), and makes theory hostile to 'mere' practice. In most types of poststructuralist theory, context invades, disrupts and mangles whatever actual practice it finds, and theory itself usurps the place conventionally given over to practice. The theorist's suspicion of the 'theoretically naive' practitioner, possibly still grounded in the former's unacknowledgeable envy of the latter, is of course very old: as Wordsworth put it, alluding to Plato, the true opposite of poetry is not prose but philosophy. But in conversations about post-structuralism Ramanujan chose to say simply, 'I don't know what to do with it'. The statement is disarmingly simple, but it carries a peculiar weight in Ramanujan's thought. (Dharwadker, 1999: 130)

Thus, my argument about the Indian in Indian Literature, in general, and IWE, in particular, is that the issues have been formulated as they have been, due to a strong belief in poststructuralist modes of criticism. Furthermore, if we were to seriously consider critiques of post-structuralism such as the following Bo Pettersson offers, our approach to literature as well as criticism may itself change. ${ }^{8}$ Listing his issues with current trends in Translation Studies, Pettersson criticizes excessive reliance on post-structuralism thus:

As yet I have not even mentioned the well-known fact that in many other academic quarters, such as philosophical and empirical aesthetics, historiography and sociology, the very underpinnings of poststructuralism have been severely criticized for more than two decades (despite the fact that poststructuralism - at times broadly termed postmodernism - has had a foothold in some niches of 
these fields). This critique has - as far as I know - never been adequately answered (and, most likely, cannot be). In brief, poststructuralism mainly rests on:

1. a conservative notion of language and a misreading of Saussure (see Tallis 1988/1995);

2. an (elitist) exaggeration of indeterminacy in meaningmaking;

3. an autonomous, agentless textuality and intertextuality;

4. an untenable anti-humanism (neglect of actual author and actual reader/s); and

5. a constructionist view of man (emphasis on nurture, neglect of nature)." (Pettersson)

Thus, the nomenclature 'Indian Literature' should not be seen as a claim to homogeneity, for there is no debate about contesting the homogenizing tendencies of any institution, but as simply a classifying node free of conceptual power and baggage. That is, Indian literature should be the corpus of literature produced in India, but also any literature that is about India and is relevant to the students of Indian Literature. This allows for the play of identification in literature, the simple literary act, which is crucial for any reading to occur. Identification as well as distance with names, places, emotions, and situations leads to a reading strategy that ultimately works up the faculty of imagination as well as cognition involving a free association process that ultimately leads to an experience of literature. Discussions of the Indian in Indian Literature is more a practical decisionist question for association meetings and conference proceedings. Let us now examine the second aspect of the Two Worlds theory

\section{b. Does Translation unite India?:}

In her essay on the "Nation and English Translation" N Kamala says that "...in translating Indian literary texts into English 
in India, [the aim is] ...to make the entire nation what we wish it to be-that is, unified." (Kamala N, 2000, 248). Similarly, Rukmini Bhaya Nair asks us the classic question about how the nation is produced and provides the answer as well. "How does a common 'idea of India' make itself available to a Bengali, a Kannadiga, or a speaker of Metei? Only through translation." (2002: 7) ${ }^{9}$ However, such answers proceed from some assumptions. Nair seems to assume when saying the above that India's different geographical spaces are so different linguistically, culturally and in other ways that they need translation. And they need translation in order for India to be a nation. Nair, of course, is not alone in making these claims about nationhood needing production. It is part of a larger consensus in our current intellectual milieu that allows her to do this conclusion. This consensus, however, relies on the work of a few scholars who may or may not label themselves as postcolonial scholars explicitly. In any case, as I see it, one of the chief characteristics of this consensus is an understanding that the Indian nation is a derivative discourse; an entity that follows European models of nationhood and systems of governance but one that has nevertheless negotiated modernity on its own terms (Chatterjee, "Our Modernity", 1997). This thesis is generally seen as extending to the 'absorption' of culture, democracy and other institutions of the nation and the state and other institutions, like Law. It is a thesis that is also popular amongst those who believe in celebrating 'agency' or 'resistance,' in the face of falseconsciousness and against a hegemonic nation-state. However, this thesis is not always pushed further to either actually elucidate how it is we function, given that we have absorbed these institutions in an 'Indian'/'our' way. On the contrary, we have as part of the same consensus, scholars who claim that the reason for India's backwardness, socially, culturally and economically lies in its slow approach towards modernity and in its incomplete attainment of nationhood. There are yet others to whom there is nothing Indian at all to be found and that to suggest so would amount to essentialism. In any intellectual forum today, one can only lay claim to an 'I' and make subjective statements and almost never can say 'our'. The goal here is to abstain from representing 
others inaccurately. One is challenged with questions about who one is 'speaking for', what violence the act of representation involves and so on. While I see this as amounting to a trivialization of the real concern for the underrepresented or the wrongly represented within India and of India abroad, the graver problem is that all these different positions of both claiming 'Indianness' and abstaining from doing so, co-exist. Such an intellectual milieu has other corollaries that are problematic.

It occasionally works with a Spivakian anti-theory position ${ }^{10}$ that results in either no representation at all or a'strategic representation'. And then again we are at a dead-end when we ask who can decide how'strategic representation' should be done. There is also an unclear premise about reality and representation that is frequently referred to, leading only to increasing ambiguity. In such an intellectual milieu, reality is supposedly inaccessible and each person can only speak for him/herself and that would constitute only his/her reality. Also, one wonders if the 'our' in Partha Chatterjee's "Our Modernity" refers to the same aspects as the word'Indian.'To say'Indian'or'Indian culture' today is more than an ordinary taboo; it immediately bestows the burden of being a right-winger, commit the unforgivable sin of essentialization! In actuality, feminists, Marxists, developmentalists need forms of essentialization, strategic or not, to practice their philosophies. ${ }^{11}$ That is, not all essentialization are wrong; neither are they fallacious or unnecessary.

That there is nothing Indian, and that Indian culture does not exist, because India was formed only in 1947 is yet another politically correct form of anti-essentialist assertions in postcolonial scholarship. Yet, there are simply too many Indians who believe too much in 'Indian culture.' This prompts us to look for concepts that allow for a reworking of current critiques of nationalism and nationhood and rework their dynamic in the case of India. It is my belief that we have alternatives in Ashis Nandy's concepts, ahistorical and memory-based cultures. Instead of concluding that Indians need an attitudinal change or a new 
social reform programme, perhaps we should make our concepts work for us and account for realities and phenomena.

Take the other crucial aspect of the current scholarly consensus, colonialism. We are told is that it has had deep effects, psychological, subtle and is not easily decipherable. Homi Bhabha (1994) claims that the slave becomes 'like the master, but not quite' and that the slave is caught in an inescapable act of mimicry. This claim is a psychological one and is excessively theoretical and abstract; entrenched largely in disciplines of Philosophy and Psychology to be evident. While our intellectual milieu mostly functions from Bhabha's thesis, alternate ideas of the master-slave relationship have always been available. See for instance, Ajit Chaudhury's work on colonialism that suggests a collaborative aspect to the relationship between the colonizer and the colonized. Ashis Nandy's The Intimate Enemy is another good example. Here, Nandy locates a number of responses on the part of the colonized, many extending from practical attitudes to deeply philosophical ones. In this light, even the Subaltern Studies project can be seen as recording the agency of the natives, a move away from Bhabha's own somewhat linear position. The history of "prose of counter-insurgency" by Ranajit Guha has an air of negotiation and active resistance, not imitation of the colonizer. Other responses to the colonizer include shaming the colonizer through everyday acts of naming the toilet as London or America, for being administrative or cultural oppressor.

The question we need to ask here is whether mimicry took over in such proportions that the native ways of being were completely lost and if yes, exactly how. Instead of inquiring into the precolonial past to seek answers for such questions, most studies see 'tradition' as something to be disdained, be embarrassed about, and disowned even. Much is pre-decided and vague and there is an ambiguous stance about the nature of pre-colonial India. Often, a straight-forward question about the nature of pre-colonial India simply dissipates into an elaboration of the complexities in such a question that then lead to meta- 
level discussions that are tangential to the basic line of enquiry. Questions about India's precolonial past quickly get termed as reactionary or 'a quest for origins' that can only be driven by nostalgia. Pollock articulates this predicament aptly while tracing the history of the diminished state of research on classics in India:

Those who could not or would not try to understand the past wound up either stipulating the very enterprise to be conceptually impossible-colonialism, we were told, imposed an epistemic barrier whose untranscendability was somehow known a priori-or condemning it as inevitably reactionary. It took years before a serious history of colonialism was understood to presuppose a serious history of precolonialism, but by then the greater part of a generation of scholars was lost to the study of historical languages." (2011: 32)

That disciplines like History, Sociology and Cultural Studies work with simplistic ${ }^{12}$ understandings of power is yet another problem. ${ }^{13}$ Our current intellectual milieu views history as driven by a quest for power and engages in the analysis of the powerful and the subjugated. Foucauldian ideas are used in specific ways for this. Yet a deep enough contextualization of Foucault's work would reveal that his formulae on subjecthood and power were almost entirely an analysis of Europe. Foucault's theory for India or Asia is almost completely asymmetrical to the one he proposed of Europe. ${ }^{14}$ Furthermore, ideas are freely taken from Hegel, Althusser and Derrida, and are used to produce a mixture of ideas about language and statehood as if their analyses can indeed be taken freely from the disparate fields they were engaging with, without qualifiers; Philosophy, Political Science and Literature. This happens despite critiques engaging in an elaborate questioning of how Hegel and other European gurus can be relevant to analyze India. ${ }^{15}$ Quite evidently, European scholars were not only talking of different continents but also at times of different centuries. The usage of these ideas freely has resulted in the production of an unsusbstantiable, but, difficult-to-challenge web of ideas and 
concepts each intricately made to relate to the other so that it is not only epistemologically unstable but also politically precarious. That the aforementioned European scholars rarely refer to Indian society, yet are 'applied' independent of their contexts.

For instance, how do we account for this verse that is recited every time a ritual is performed? "Jambudveepe bhaaratavarshe kumarikakhande, aryavartaikadeshe...srisvetavarahakalpe ... manvantare astdvinsatitame kaliyuge prathamacharane..." This verse indicates the exact area of one's physical location, country, year, heritage and history in very specific ways that though lead to an identity, is not similar to that offered by nationhood. Also, there are verses that recite the names of the rivers of India on all sides, and literally map the geography of India. How do we account for these verses and still claim that there is no cultural selfunderstanding of 'India' as a whole, emerging from pre-colonial India? Pollock is probably a rare scholar who can explain this.

... the conceptual order of Sanskrit geography in its mature form, focusing on Bhāratavarșa, was uniform, stable, and, most significant of all, subcontinental [my emphasis], and this limit, once achieved, marked the boundary of geographical concern. But this was a boundary unlike any other. If in some important respects it excluded many spaces ... the excluded [peoples] often claimed inclusion by the very act of naming wherever they lived with the names of India. 'India' was moveable and multiple. (2009: 193). ${ }^{16}$

What I am proposing is that we could view bharatvarsha as different from the imagined community of India, the nation. To formulate it as a question, we would have to ask: How can we be sure that the earlier India or bharatvarsha has been replaced by India, the nation? Could not bharatvarsha persist in some forms in the memories of people, if not in histories and through common practices, ideas and rituals? ${ }^{17}$ Can we thus question the following consensus in Literary and Translation Studies?: "While various notions of India-indeed, various Indias - may have preexisted British colonization, this one monolithic nation, India, was 
constructed only in English translation." (Kamala, N, 2000: 245)

Irrespective of the different sub-theses proposed, most theorizations of the nation and its avatar in India tell us that contemporary India and pre-colonial India both lack unity and lead us to believe indirectly that 'centralizing' is the best form of governance. In fact, the pre-colonial history of India is reconstructed in such a way that we can only see warring tribes and small kingdoms throughout. ${ }^{18}$ This is not only anachronistic; it is a conclusion guided by European-Western notions of statehood and governmentality and is Orientalist in nature. What we see in the Sanskrit verse quoted above is an assertion of a certain kind of heritage that could accompany localized governance and have been the order in pre-colonial India. The question that we should to ask is, what might have sustained the kinds of assertions that we see in the verse? That is, what enabling conditions allowed a person to identify himself or herself based on his/her regional location as well as, in other contexts, lineage. Why were these identifications considered important in contexts of the performances of ritual?

The discussion of language and nation-formation in conjunction also follows the discussion in Europe in the 1930s and earlier. In other words, the peculiarity of nation formation in India remains under-researched in independent terms. Hence, we could safely conclude that Rukmini Bhaya Nair's understanding that 'the idea of India becomes available only through translation' could be a debate derivative of the context wherein English Literature was made to represent Britain as superior in comparison to European nations while each of the European nations competed with the other to create their identity. ${ }^{19}$ Since the contents of 'the Indian way of nation-building' remain lost to us in such understandings as Nair's, it is as if there is no difference between India and Europe and the problems of the two geographically and culturally distinct places were all just the same. All these oversights and derivative discussions actually amount to Orientalism. They exhibit a logical sophistication but lack intelligibility.

The scholarly consensus on nationhood ignores the role 
of 'jaati relations' that guided social life in both pre-colonial and present India. Much of our intellectual milieu is preoccupied with assessing the social value of 'jaati' or caste system. The importance of these relations emerges better when one takes into account, usages such as "Kannada Brahmin" or "Telugu Shree Vaishnava." What is revealed in these usages is the multiplicity of identities that involves region, language as well as jaati. Perhaps the complexity of these usages eludes us because we assume that all cultures have religion ${ }^{20}$ and that these identities have originate from religion. Our assumptions that Hinduism is a religion and that the caste system is an evil that needs eradication, because the priests disallow access to God lead us to draw analogies exactly like the priests of the pre-renaissance church in Europe. These, in reality, amount to more examples of Orientalism. The continuation of such analogies and the accompanying problems become clear when one reads travel accounts, even from as early as the $13^{\text {th }}$ century. See for instance, Duarte Barbosa's accounts of India. ${ }^{21}$ In order to account for the differences that India, its culture and society displays, the jaati scheme of things must be studied seriously without an assessment of its value as an institution and our current understanding of plurality reexamined. Although scholarship is limited in this area, one sees very relevant analysis emerging in the writings of Ashis Nandy ${ }^{22}$ and Dharampal's five volumes of writings that explicate his understanding of village society and economics before and during British administration. What is lacking in scholarship, interestingly enough, is available in literary writings. This refers us back to issues about literature and theory raised earlier. Examples of fiction accounting for the complexity of cultural issues can be found in the work of Sadat Hasan Manto. An example from regional literature would be Shridhara Balagara who views jaati scheme of things, not as caste system per se but as identities formed through migration.

The scholarship on nationhood and colonialism are so rift with problems that we may have to rework this train of thought if we want to understand the position and presence of English in India, its gaining popularity in translation or understand 
the accompanying anxieties for our vernacular languages, as expressed in the Two-Worlds theory. What also becomes suspect is the claim that translation produces nationhood. The claim that nationhood needs to be produced through translation ignores the social relationships that were not based upon knowing the same language or on notions of unity or affiliation. Could it not be the case that commonalities and differences that exist inseparably in one's consciousness are less spoken about, are unacknowledged and unrecognized even, which when probed through current derivative concepts appear non-existent or as achieved through a specific production processes?

Is there not after all a relationship that still sustains in the face of another who may speak a different language and follow different practices and customs: a relationship that recognizes the other as the other?

Furthermore the claim that it is translation that enables a Kannadiga and Metei to relate to each other is fraught with more problems, since the notion of translation implied here is not clear. If we have a linguistic translation in mind, then the point is trivially true. But if it is cultural translation that is being referred to here, then even more lack of clarity takes over. It is probably a claim that is made with the understanding that there are too many different cultures and different language in India for any communication or fellow-feeling to become possible. But we should note that the notion of culture used here assumes that culture lies in differences of language, cuisine, dressing, practices, customs and so on. Even the definition of culture as 'a way of meaning making' only refers us back to these categories. In fact, culture is increasingly seen as a creation of the nation so that the nation can sustain itself. Culture is seen as the space where politics is played out and this is noted in Interrogating Modernity. ${ }^{23}$

...culture as 'a site of convergent interests rather than a logically or conceptually clarified idea'. The field of culture is seen as 'a constant battlefield' where there are no victories to be gained, only 'strategic positions to be won and lost'. 
Cultural practices become real where one engages with and elaborates a politics. (Introduction, Interrogating Modernity)

Interestingly enough, it is only in literary writings that we find a somewhat broad notion of culture. Here, there is chance of referring to culture as the 'inner life of human beings' and as 'what sustains humans in times of calamity'. ${ }^{24}$ If we had a different, more substantive notion of culture, would it shed different light on the Two-Worlds theory? Would our anxieties about the native vernacular languages be any different or any less? I think that this is an important question. Let us examine a different understanding of culture now to probe further.

\section{Culture:}

"Neither the word, nor the text, but the culture becomes the operational 'unit' of translation" (Lefevere and Bassnett 1990: 8). This is the claim of the cultural turn in translation. Yet, as we saw above culture can often be restricted or left vague. The definition of culture as ways of meaning-making appears more like an exposition of social constructionist theories rather inquiring deeply into, 'what sustains humans in times of calamity.' If one allows for this understanding of culture then, there is an intertextual and intra-textual relationship among the languages as well as the culture of India. Other modes of signification and subjectivation, such as ritual observances, cultural practices and myths cut across different languages and customs. Thus, if the nation-state was a recent entity, the linguistic division of states was one as well. Differences in Indian regions could thus also be similar differences. For instance, streedharma in Rajasthan is different from that of streedharma in Tamil Nadu but that streedharma is an object of thought, debate and response is itself a fact that unifies Indian regions. As Pollock's quote earlier indicated, this logic could be extended to identify aspects unique not just India but also Asia. Similarly, the attitude with which menstruation is traditionally held, is exactly opposite, in different parts of India. While it is a taboo in certain regions, it is auspicious in others. Yet, that menstruation was seen as an occurrence demanding some 
kind of structured response, making sense and so on, is somewhat unique to experience of Indian living.

Such understanding of culture give us a sense of things always being in the middle, with no narrative to bind events. I find Dharwadker's critique of Niranjana useful in articulating this. According to Dharwadker, Ramanujan uses a different starting point:

Unlike Homi Bhabha, for instance, who is concerned with demonstrating that all identities are ineluctably ambivalent and hybrid in the end, Ramanujan accepted the hybridity of languages and cultures as a starting point and tried to show, instead, how different degrees and kinds of hybridization shape particular languages, and how, despite the universal fact of mongrelization, no two mongrels are actually alike. (1999: 128)

The hybrid notion of culture that Ramanujan draws from is also notion of culture that Amitav Ghosh's work explores. Though Ghosh writes novels, they are well-researched and often based on archival evidence that is then weaved together. In a novel like Shadow Lines, Ghosh's point is not merely that the nation is new and imagined but more. He views geographical and cultural spaces as necessarily porous, unbounded and continuous. In both Ramanujan and Ghosh's understanding, there have been ongoing conversations between cultures forever. It appears that the absence of a historical record to demonstrate this is irrelevant since all events need not be recorded in historical cultures even and ahistorical cultures only work with memory.

Cultures, nations, civilizations, however we may term the object of 'what sustains humans in calamity,' we do seem to remain in the middle of things, with no necessary point of origination or conclusion. Only in stories of a certain narrative structure or order may we see a false sense of order imposed on the fluidity of things. In strong contrast to western narratives, Indian stories lose this sense of order while they journey within or without a 
regional space. The many Ramayanas and Mahabharatas are possibly the best illustration for this. If, even hypothetically, we view the journey of texts like the Ramayana and the Mahabharata as acts of translation, we perhaps arrive at an indigenous theory of translation. Of course, the texts and their contexts would be as peculiar as to their times and contexts. I believe that we should view Mini Chandran's introduction to the Macmillan series in this light; a work that has been critiqued as patriotic in sentiment.

Balagangadhara (1994) theorizes culture as a configuration of learning. His essay "Notes Towards a Study of the Caste System" elucidates a theory of culture thus:

The configuration of learning organises (or structures) the going-about of individuals with one another, and their goings-about the (salient diversities in the) natural environment... Even though this is but a partial explication of the notion of 'configuration of learning', it already helps us realise that there is a significant difference between 'learning' ('the process of creating a habitat'; 'that which makes the environment habitable') and 'a configuration of learning'.

Balagangadhara further suggests that we think in this vein:

Human individuals are born simultaneously into cultural and natural environments. Both these environments are incredible storehouses of differences. We can look at these environments as 'spaces': a natural and a cultural space. However, what the human child learns, also through the process of teaching, are not mere 'differences' in these two 'spaces', but salient diversities. That is to say, through a process of selection, some differences are bracketed away, some differences are clustered, some are emphasized, etc. These are structured sets of differences that we may call salient diversities. A configuration of learning helps individuals to cope with salient diversities. (ibid) 
And,

Since any group that has lived for any significant period of time survives only as a culture (i.e., as 'a configuration of learning'), each one of us in the world encounters only salient diversities. (ibid) $)^{25}$

This theory of culture talks about learning, teaching and the mechanisms involved in this process. It resonates with Bo Pettersson's objections to post-structuralism. Understandings of culture as something that helps us cope with salient diversities indicates that culture is made up of at least two levels of reflective processes. From definitions of culture that see it as 'a way of meaning making' to this one, we see a shift that shows two levels of a process of reflection and learning and teaching. Instead of wondering how or what notion of culture is applicable to the specific geographical space of India, we can now think of culture in broader, formal terms and as a structuring. This allows us to adopt a somewhat content-less mode, rather than a set of principles about a certain geographical space. A set of principles about a certain geographical space would sooner or later run into problems, because it would not be able to accommodate changes as quickly as they occur and would render the culture and its people stagnant-an orientalist stance-according to Edward Said.

Within the above charted theory of culture, differences can sustain, because learning-teaching methods abound in quantity to suit the temperament of both learners and teachers and the general reflective process. While mere learning would refer to making the environment habitable, doing so in a systematic manner or identifying the salient diversities of natural or cultural environments is culture. It is thus that culture thus is a configuration of learning. We could, with this understanding of culture account for variant traditions, versions of plurality or the 'many cultures' of India.

In a simplistic understanding of culture, one would 
presume that simply coming from a certain culture contributed to one's identity, or that a language, cuisine, dressing or climatic condition contributed to one's identity. While these entities may be seen as shaping our identity, if we do indeed get habituated to them, the theory of culture explored above only yields more information. A configuration of learning does not necessarily produce an identity. Its interest lies elsewhere. The following quote should add clarity:

...Its [Asian culture/India's] way of going-about solves the problem of 'How to live' not by building a world view but by developing among their members an ability to try and live the best way they can. That is to say, such is their way of learning that it teaches one how to live. Not by imparting knowledge about the world, but by imparting practical knowledge. (Balagangadhara, 1994:461)

In such a scenario, practices abound, and does not lay claims over identity, instead of struggles. The notion of practical knowledge renders the 'word as mantra' system of Indian languages meaningful, but we cannot go into the details for want of space. With the theory of culture as a configuration of learning, we are presented with the possibility that what unites the geographical space that is India is a configuration of learning and that translation may be only secondary in such a process (as in translation from one language to another or linguistic translation). If a configuration of learning preserves itself in multiple ways and its social organization is in such a way that practices appear contrary, then we now know why there exist many traditions in India, and why we sometimes perceive them as 'paradoxical.' If a configuration of learning is far more than a language, a custom or practice, and is a how, then the question I would formulate is: why should we be so anxious about a language and its status?

Much of our discussions about languages and the anxieties of the Two-Worlds theory are based in our understanding of Structuralism and Post-Structuralism's notions of language and thought and their relationship. With an alternative understanding 
of culture, we could instead say, that a language may house a configuration of learning, and that it cannot itself be the configuration of learning. If such is indeed the case, then the diminishing power of a language is a problem of a different order.

Mainstream theories of language and culture work from the understanding that languages represent or house a culture and that a loss/extinction of a language necessarily indicates the loss of a culture as well. Here is where perhaps Derrida's correction of Sausserian theories and his subsequent pointing to the East as a place where language follows different rules might finally become useful. ${ }^{26}$ In fact, language in the Indian culture, one could say, is not bound or shaped by the cultural, in the same way in which meaning-making (which is based on a transcendental signified) is in the West. Meaning-making and truth, both because of the direct relationship between language and culture in the West, it could be argued, became intricately attached to Christian history and ultimately became fully derivative of it. So, what I am pointing out is the possibility that the death of Sanskrit, to suppose that, has not and will not lead to the death of what may be called 'traditional or Indian ways of being'.

Let us now return to the question of English translations or even the issue of English language 'taking over' and leading to the suppressed state of the vernacular languages. Although the demise of vernacular languages is definitely undesirable, it is not undesirable anymore because there is a subsequent loss of culture. While we need to fight the hegemony of English as strongly as possible, our feeling of anxiety may be unnecessary even if English does receive a lot of attention. This is because, as we noted earlier, English has been domesticated and Indianized, giving rise to the peculiar form of 'Indian English.' In other words, English has been made to bend to suit descriptions and accounts of Indian experiences. However, the politics of domination cannot be overlooked, and more so because there is a strong narrative of humiliation written into the history of the English language, its history and its presence in India. Here again, Balagangadhara 
provides a useful theory of colonialism of which I will only share one important point here.

However, the ... perception [about colonialism] does not emerge from a scientific study of colonialism but from the rhetorical force of another question: "if colonisation is not an expression of weakness, what else is it? An expression of strength?" Even though every historian can routinely assure us that 'higher' civilizations can be conquered and overrun by 'barbarians', the studies of colonial history do not appear to have moved away from this rhetorical question. On the contrary, they try to provide 'insights' into the Indian weakness, and tell us what the latter were. Of course, the strengths of the coloniser appear obvious. There is the emergence of the natural sciences that predates colonialism; and then there is the industrial revolution that postdates colonialism. The popular consciousness has telescoped both these events into a single state of affairs: the scientific, technological and the military might of the West. The consensus (more or less) is that colonialism expresses the 'weaknesses' of the colonised and the 'strengths' of the coloniser. (Balagangadhara and Bloch, "Colonialism, Colonial Consciousness, and Political Theory," 2008)

So, the seeing of a rhetorical question as a literal one has led us to anticipate and even accept a certain weakness, or effeminateness (as our colonizers would put it) on our part. It was possibly such humiliation that led to giving undue importance to the English language in the initial years after independence. With the postcolonial understanding of English as a conqueror's language or the language of the powerful, it seems to have had an overbearing influence upon us. It was possibly this same strain of humiliation that led India's upper class and privileged to pretend that English was somehow liberating. Steered clear of the narrative of humiliation and its other effects, it should be possible for us to view English as just another language, minus current. English then can be seen simply as a language for communication 
and for the first time can be assessed for its appeal or the lack of it and for its effectiveness in describing Indian life-experiences.

In conclusion, we could say that Nair's statement about translation producing India relies on certain theories of nationhood, colonialism and limiting definitions of culture. We could hypothesize that what produces or unites India is its cultural realm, which finds different expressions in its social realms. In extension, we can perhaps see 'Indian Literature in English Translation' and the trends emerging in relation to it as representing the fact that we have learnt and made, another language our own. And that the spur in English language activity possibly only indicates an increased awareness about the unique place of India and its Literature in relation to the world. This realization is probably what produces the demand for more translations and with time, these translations will also clear the confusions that persist about India in Western minds without leading to textualization. Thus, with alternative understandings of concepts and phenomena like culture, colonialism, and Orientalism, the anxieties represented by the Two-Worlds theory change and diminish and can aid us in arriving at new ways of addressing some very crucial issues in Translation and Literary Studies.

\section{NOTES:}

1. This paper was presented in Tiruvananthapurm in 2008 under the broad area, 'Indian Literature in English Translation and Nation building' indicated in the concept note for the seminar Translating India into English organized by the University of Kerala. I thank Dr. Giridhar P P for his valuable comments on the presentation.

2. One has to only remember the song, "Why this kolaveri, kolaveri di..." English as a gender marker is crucial given the statistics that reveal that girls do better at exams and in general school and studying across India.

3. Salman Rushdie's praise for Indian writing in English asopposed 
to the vernacular writings of India in his introduction to The Vintage Book of Indian Writing is significant in this context. It became controversial and raised concern in the literary world. Rushdie's remarks saw a response in Amit Chaudhuri's work.

4. Since travelling to the Unites States of America, I have developed some faith in the usefulness of audio books for people who speak but cannot read or write in a certain vernacular or mother tongue. In most parts of the USA, local community libraries have at least one audio copy of the books they hold. Perhaps awareness that plays and novels are better heard, with intonation, helps. But such an awareness, market and audience needs to be created in India through the technological expertise.

5. See Meenakshi Mukherjee (1993), Kothari (2003).

6. Madhu Kishwar's "Obstruction as Ideology" in Outlook is relevant here (http://www.outlookindia.com/article/ obstruction-as-ideology/231135). Sasheej Hegde too critiques Partha Chatterjee for the understanding of nation as constitutively possessing qualities.

7. Similarly, Amit Chaudhuri points out how authorial choices remain important for drawing the boundary within which meaning-making occurs. This is a position that asserts that the author is not unimportant, not, 'dead.'

8. For more on critiques of post-structuralism, see this link: http://www.brocku.ca/english/courses/4F70/poststruct.php

9. Cited in Rita Kothari, 2003.

10. See: Spivak, Gayatri Chakravorty. The Post-Colonial Critic: Interviews, Strategies, Dialogues. Ed. Sarah Harasym. New York \& London: Routledge, 1990.

11. An informative gloss here is Susie Tharu's position on the role of ideology. See her essay on Women Writing in India in 
Journal of Arts and Ideas for this.

12. They are based on one essay by Foucault, Michel. 1980. Power/ Knowledge: Selected Interviews and Other Writings, 1972-1977. Ed. Colin Gordon. New York: Pantheon.

13. Different understandings of Foucault like that of Donald Davidson are completely ignored by these scholars. See: Davidson, Arnold I. 2001. The Emergence of Sexuality: Historical Epistemology and the Formation of concepts. Cambridge: Harvard University Press. For a complete elucidation of the problem with such a thesis about power, see: Ramaswamy Krishnan et al. Eds. Invading the Sacred: An analysis of Hinduism Studies in America.

14. See his History of Sexuality volumes.

15. See Chakrabarty, Dipesh. "Postcoloniality and the Artifice of History: Who Speaks for 'Indian' Pasts?" Representations 37 (1992): 1-26.

16. For a quick glimpse of similar ideas, refer to Pollock's talk in the Jaipur Literature Festival on the recently inaugurated Murthy Classical Library of India.

17. Furthermore, the development of a number of vernaculars in the 10th century is a mystery few can claim to have solved. In my doctoral dissertation, I contest the idea that the vernaculars emerged to dislodge the high position of Sanskrit through an analyses of Bhakti literature that borrows freely and wherever necessary from Sanskrit. See Kannan (2011).

18. See Romila Thapar's Early India.

19. For an elaborate discussion of the debate in France and other European countries, see: Lecercle, Jean-Jacques and Denise Riley. 2004. Force of Language. New York: Palgrave Macmillan.

20. For a very original elucidation and argumentation of this, see: Balagangadhara 1994. 
21. See: ML Dames (1989), The Book of Duarte Barbosa, 2 Vols, ASEA, Indian reprint.

22. Nandy, Ashis. "History's Forgotten Doubles." History and Theory 34 (1995): 44-66.

23. For an interesting understanding of a related problem of taking from the past what we want and its violence, See: Tharu, Susie. 1991. "Women Writing in India". Indian Journal of Arts and Ideas. Dialogue on cultural practice in India: Inventing Traditions. Numbers 20-21. March.

24. See Amit Chaudhuri's edited volume on Indian literature, The Picador Book of Modern Indian Literature, for glimpses of this definition of culture.

25. This essay is uploaded and freely available on the web for those who register with yahoo group that discusses Balagangadhara's book. To access this essay, follow this link: http://groups.yahoo.com/group/TheHeathenInHisBlindness/

26. Derrida, Jaques. 1967. Writing and Difference. Trans. Alan Bass. London and New York: Routledge.

\section{REFERENCES:}

Balagangadhara, S N. 1994. 'The Heathen in his Blindness...' Asia, the West and the Dynamic of Religion. Leiden, New York, Koln: E J Brill.

Balagangadhara, S N. 2002. "Notes Towards the Study of the Caste System in India". Unpublished Paper. Available at link: http:// groups.yahoo.com/group/TheHeathenInHisBlindness/

Balagangadhara et al. 2008. "Rethinking Colonialism and Colonial Consciousness: The Case of Modern India." in S. Raval (Ed.), Rethinking Forms of Knowledge in India. Delhi: Pencraft International, pp. 179-212.

Balagara, Shridhara. Ondu Photoda Negative. Ankita 
Pustaka.

Dharwardker, Vinay. 1999. "Ramanujan's Theory and Practice." In Susan Bassnett and Harish Trivedi (eds). Postcolonial Translation: Theory and Practice. London and New York: Routledge. pp 114-140.

Bhabha. 1994. The Location of Culture. London and New York: Routledge.

Chakrabarty, Dipesh. "Postcoloniality and the Artifice of History: Who Speaks for 'Indian' Pasts?" Representations 37 (1992): 1-26.

Chandra, Vikram. "Cult of Authenticity: India's cultural commissars worship 'Indianness' instead of art." Boston Review in March 2000.

Chatterjee, Partha. 1986. Nationalist Thought and the Colonial World: A Derivative Discourse? London: Zed Books.

Chaudhury, Ajit. 2000. Margin of margin: Profile of an unrepentant postcolonial collaborator. Calcutta: Anustup.

Chaudhuri, Amit. Ed. 2002. The Picador Book of Modern Indian Literature. Picador.

Davidson, Arnold I. 2001. The Emergence of Sexuality: Historical Epistemology and the Formation of concepts. Cambridge: Harvard University Press.

Dames, ML. 1989. The Book of Duarte Barbosa, 2 Vols, ASEA, Indian reprint.

Derrida, Jacques. 1967. Writing and Difference. Trans. Alan Bass. London and New York: Routledge.

Devy, G N. 1995. "Multiculturalism." In In Another Tongue: Essays on Indian English Literature. Madras: Macmillan. Pp 13-19.

Foucault, Michel. 1980. Power/Knowledge: Selected Interviews and Other Writings, 1972-1977. Ed. Colin Gordon. New York: Pantheon. 
Ghosh, Amitav"The Fundamentalist Challenge." The Imam and the Indian: Prose Pieces (New Delhi: Ravi Dayal and Permanent Black, 2002) 282-3.

Kamala, N. "Gateway of India: Representing the Nation in English Translation. In Changing the Terms: Translating in the Postcolonial Era. 246-259.

Kannan, Sushumna. 2011. Akka Mahadevi-a Rebel, Saint and Poet?: A Study in 'Tradition' and its Feminist Understandings. Unpublished PhD Dissertation.

Kothari, Rita. 2003. Translating India: The Cultural Politics of English. Delhi: Foundation Books Pvt Ltd.

Lecercle, Jean-Jacques and Denise Riley. 2004. Force of Language. New York: Palgrave Macmillan.

Mani, Lata. 1998. Contentious Traditions: The Debate on Sati in Colonial India. Delhi: OUP.

Mannur, Anita. "The Changing Face of Translation in Indian Literature." In Changing the Terms: Translating in the Postcolonial Era. pp 227-243.

Mukherjee, Meenakshi. "The Anxiety of Indianness: Our Novels in English." EPW, Vol. 28, No. 48 (Nov. 27, 1993), pp. 2607-2611.

Niranjana, Tejaswini. 1992. Siting Translation: History, Poststructuralism and the Colonial Context. Univ. of California Press.

Niranjana, Tejaswini et al. Eds. 1993. Interrogating Modernity: Culture and Colonialism in India. Calcutta: Seagull.

Pettersson, Bo. "The Postcolonial Turn in Literary Translation Studies:

Theoretical Frameworks Reviewed." http://www.uqtr.ca/AE/vol_4/ petter.htm

Pollock, Sheldon. 2009. Sanskrit, Culture, and Power in Premodern 
India. Berkeley: University of California Press.

Pollock, Sheldon. 2011. "Crisis in the Classics." Social Research. Vol. 78, No. 1, Spring.

Ramaswamy Krishnan et al. Eds. Invading the Sacred: An analysis of Hinduism Studies in America.

Rushdie, Salman and Elizabeth West. Eds. The Vintage Book of Indian Writing. 1947-1997. Vintage.

Said, Edward. 1978. Orientalism. New York: Vintage Books.

Spivak, Gayatri Chakravorty. 1990. The Post-Colonial Critic: Interviews, Strategies, Dialogues. Ed. Sarah Harasym. New York \& London: Routledge.

Tharu, Susie. 1991. "Women Writing in India."Indian Journal of Arts and Ideas. Dialogue on cultural practice in India: Inventing Traditions. Numbers 20-21. March. 